INTERACTION: Jurnal Pendidikan Bahasa: Vol. 5, No.1: Mei 2018

ISSN: 2406-9558; E-ISSN: 2406-9566

\title{
The Application of Presentation Method to Increase Student's Ability in Explaining Cases
}

\author{
Ismawati \\ ismawati@gmail.com \\ Man Model Sorong
}

\begin{abstract}
This study was carried out with the purpose to measure the effectiveness of Presentation Method in increasing students' ability in explaining cases. This study is quantitative research. Quantitative research was used as the mean in collecting the data. The population of this study was the students at the Second Grade of MAN Model Sorong in the years 2014/2015, by the number were 208 students. The sample of this study was the students of XI IPA 2 by the number were 30 students and XI IPA 3 by the number were 28 students. The writer used pretest- posttest control group design of true experimental design in this study. The result of study was presented into tables and had explained by percentage. In analyzing data the writer used the application of SPSS 18. The result of this study showed that there was an increasing score of students at experimental group. The mean pretest of both experimental group and control group before were 45. Then after treatment was given to experimental group the mean was 80. But the mean of control group was 40,25. It means that Presentation Method is effective to increase students' ability in explaining cases. The result of this study showed that the $\mathrm{T}$ value $>\mathrm{T}$ table $=17.667>2.093$. It means that the hypothesis of this study was accepted. The writer concluded that Presentation Method can increase student's ability in explaining the cases.
\end{abstract}

Key words: Presentation Method, Explaining Cases.

\section{INTRODUCTION}

Communicative competence in learning English as second language or as foreign language has been the first and main goal. With communicative competence, the students are able to express ideas or opinions orally in public. But, in the fact the students have problem when they would express their opinions in public. This is because the students are not accustomed to speak in front of class and lack of confidence.

Explaining cases is the most important skill in communication by using language as a tool to communicate. With speech students can explain their opinions and ideas. With speech students can explain their opinions and ideas. 
According to the fact, it is necessary to present a method that can improve student's ability to explain cases. In order to get optimal learning result, the selection of appropriate learning method is crucial. Therefore, to improve the student's ability in explaining cases may be done by the method of presentation.

According Oxford Learner's Pocket Dictionary (2008), Presentation is an act, a way, or a meeting that something is presented to somebody. The purpose of this method is to train students to develop activity and ability to think critically and analytically.

\section{LITERATURE REVIEW}

\section{Previous of Study}

Anggraeni M.S Lagalo (2012), he has research on "the application of presentation method to increase students ability at the tenth gradestudents of man Batudaa". The second research is conducted by Munali (2013), with his research paper entitle "improving student's speaking ability through presentation at the second grade of MA Muhammadiyah Aimas".

This research with previous studies uses the same method. That is use the presentation method. In this research, the writer will investigate about the influences of presentation method to increase student's ability in explaining case.

\section{METHOD}

\section{Design}

In this research, the writer will use pretest- posttest control group design of true experimental design.

For clear the description about how the research will be conducted through following figure below:

\begin{tabular}{|lll|}
\hline CG=T1 & O & T2 \\
\hline EG=T1 & $X$ & T2 \\
\hline
\end{tabular}

CG : control group

EG : experimental group

T1 : Pre test to measure means of student's achievement before doing treatment.

$\mathrm{X} \quad$ : Applying presentation method in teaching 
INTERACTION: Jurnal Pendidikan Bahasa: Vol. 5, No.1: Mei 2018

ISSN: 2406-9558; E-ISSN: 2406-9566

T2 : Post test, to measure the means of student's achievement after doing the treatment.

$\mathrm{O} \quad$ : teaching by conventional method

\section{Analysis Data}

Data analysis is the process of arranging the data sequence categorize it into a pattern, category and description of the base. In processing the data, the writer use SPSS version 18.

\section{RESULT AND DISCUSSION}

\section{Results of the Research}

Result of this study showed that there was increasing scores of students at experimental group. The mean pretest of both experimental group and control group before were 45 . Then after treatment was given to experimental group the mean was 80. But the mean of control group was 40,25. It means that Presentation Method is effective to increase students' ability in explaining cases.

Then the result of hypothesis testing previously showed that $\mathrm{H} 1$ is accepted because $\mathrm{t}$ value $>$ t-table $=17,667>2,093$.

\section{Description of Research Data}

In getting the data, the writer took two classrooms action properly, the first classes become the control group and the second was the experimental group. The writer gave the test and treatment as an explanation, so that the students understood more especially in explaining cases.

\section{Presentation Method Increase the Student's Ability in Explaining Case.}

The writer gave posttest to the both experimental and control group, to know the effectiveness of the method. The posttest form was interview between teacher and students.

\section{Student's Ability in Explaining Case}

To start the study, the writer started from formulating problem and the problem is the student's ability in explaining case at Madrasah Aliyah Negeri Sorong is low. To know more information about it, the writer formulated the problem in form of research questions which must be answered by collecting the data from the sample of the study. The form of pretest was interview. Numbers of the questions were ten questions and the questions were very simple, that asked about their specific information of themselves. 


\section{Basic Testing Analysis}

\section{Presentation Method to Increase Students' Ability in Explaining Case}

To know whether the Presentation Method increase student's ability in explaining case or not, we can see the result of posttest of the students as follow;

Table 1. A

The Posttest Score of Experimental Group and Control Group

\begin{tabular}{|l|l|l|l|l|l|}
\hline \multicolumn{2}{|l|}{ Experimental group (x1) } & \multicolumn{3}{l|}{ Control Group (x2) } \\
\hline No & Subject Name & Score & No & Subject Name & Score \\
\hline 1 & A & 75 & 1 & A & 35 \\
\hline 2 & B & 80 & 2 & B & 45 \\
\hline 3 & C & 85 & 3 & C & \\
\hline 4 & D & 85 & 4 & D & 35 \\
\hline 5 & E & 75 & 5 & E & 40 \\
\hline 6 & F & 85 & 6 & F & 45 \\
\hline 7 & G & 90 & 7 & G & 35 \\
\hline 8 & H & 70 & 8 & H & 40 \\
\hline 9 & I & 90 & 9 & I & 40 \\
\hline 10 & J & 75 & 10 & J & 30 \\
\hline 11 & K & & 11 & K & \\
\hline
\end{tabular}


INTERACTION: Jurnal Pendidikan Bahasa: Vol. 5, No.1: Mei 2018 ISSN: 2406-9558; E-ISSN: 2406-9566

\begin{tabular}{|r|l|l|l|l|l|}
\hline 12 & L & 90 & 12 & L & 35 \\
\hline 13 & M & 75 & 13 & M & 50 \\
\hline 14 & N & 80 & 14 & N & 45 \\
\hline 15 & O & 75 & 15 & O & 45 \\
\hline 16 & P & 80 & 16 & P & 30 \\
\hline 17 & Q & 75 & 17 & Q & 40 \\
\hline 18 & R & 80 & 18 & R & 40 \\
\hline 19 & S & 75 & 19 & S & 40 \\
\hline 20 & T & 80 & 20 & T & 45 \\
\hline & SUM & 1600 & & SUM & 805 \\
\hline & MEAN & 80 & & MEAN & 40,25 \\
\hline
\end{tabular}

Based on the data above, there were differences scores in experimental group and control group. On the contrary, the score of control group was not change significantly. So that, the writer concluded that Presentation Method is effective to improve students' ability in explaining case. To know more about how far Presentation Method increase student's ability in explaining case, the writer included the data result into the SPSS 18. 
INTERACTION: Jurnal Pendidikan Bahasa: Vol. 5, No.1: Mei 2018

ISSN: 2406-9558; E-ISSN: 2406-9566

Wilcoxon Signed Ranks Test

Ranks

\begin{tabular}{|ll|l|l|l|}
\hline & $\mathrm{N}$ & Mean Rank & Sum of Ranks \\
\hline After Treatment & - Before Negative Ranks & $20^{\mathrm{a}}$ & 10.50 & 210.00 \\
Treatment & Positive Ranks & $0^{\mathrm{b}}$ & .00 & .00 \\
& Ties & $0^{\mathrm{c}}$ & & \\
& Total & 20 & & \\
\hline
\end{tabular}

a. After Treatment $<$ Before Treatment

b. After Treatment $>$ Before Treatment

c. After Treatment $=$ Before Treatment

\section{Test Statistics ${ }^{\mathbf{b}}$}

\begin{tabular}{|l|l|}
\hline & After \\
\cline { 2 - 2 } & Treatment \\
& Before \\
\cline { 2 - 2 } & Treatment \\
\hline Asymp. Sig. (2-tailed) & .000 \\
\hline
\end{tabular}

a. Based on positive ranks.

b. Wilcoxon Signed Ranks Test

From the data above, there were two tables showed after the data was being counted by SPSS 18. The first table was table of Ranks, and the second table was a table of Test Statistics. From the table Ranks, it showed that $(N)$ Negative Ranks are "20". It means that there are 20 students in experimental group have scores more high than the result in control group. Then, based on Positive Ranks is " 0 ", there are no a student in experimental group who had score that has less than control group. The Mean Rank was 10.50 and the Sum of Ranks are 210.00. While, for ties there was "0", it means that there was not value after the same with before treatment. From the table "Test Statistic", it showed that the score of (Z) is -3.933 and Asymp. Sig is 0.000. 
INTERACTION: Jurnal Pendidikan Bahasa: Vol. 5, No.1: Mei 2018

ISSN: 2406-9558; E-ISSN: 2406-9566

\section{T-Test}

\begin{tabular}{|ll|l|l|l|ll|}
\hline & & & & & Std. & Error \\
\cline { 3 - 6 } & & Mean & N & Std. Deviation & Mean & \\
\hline Pair & Before Treatment & 80.00 & 20 & 5.849 & 1.308 & \\
1 & After Treatment & 40.25 & 20 & 5.730 & 1.281 & \\
\hline
\end{tabular}

\section{Paired Samples Test}

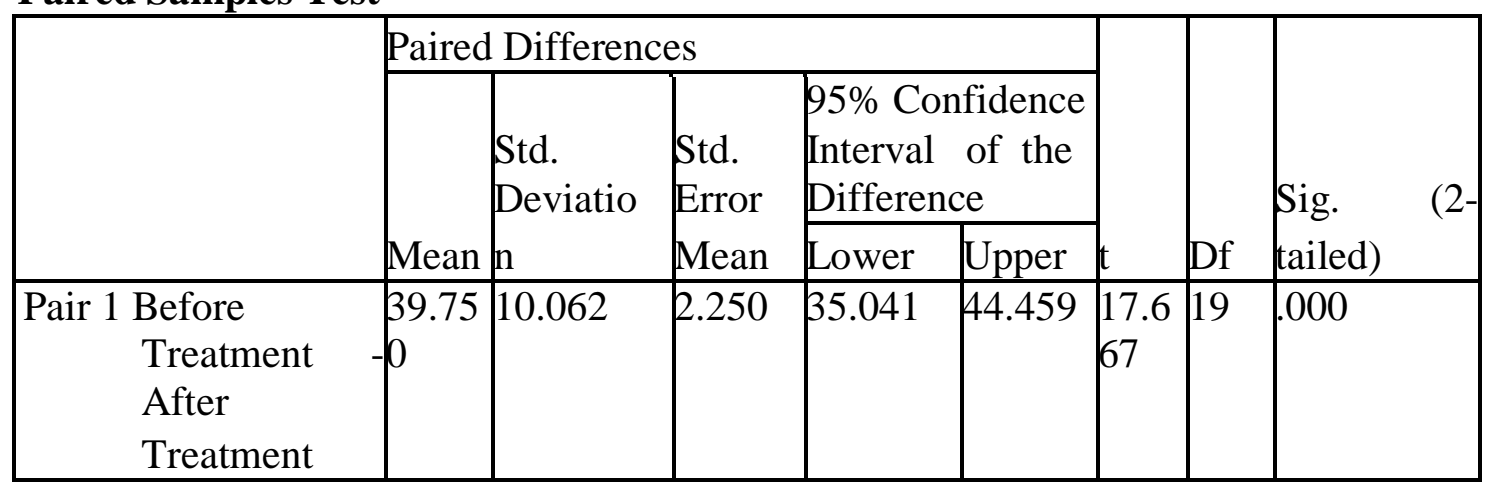

Form the table above, there were two tables showed after the data was being counted by SPSS.

The first table was table of paired samples statistics, and the second table was a table of paired samples test. From the table paired samples statistics, it showed that (N) 20, it means that there are 20 students in experimental group and control group. Then the mean of experimental group was 80.00 and in control group was 40.25 . From the table paired samples test, it showed that:

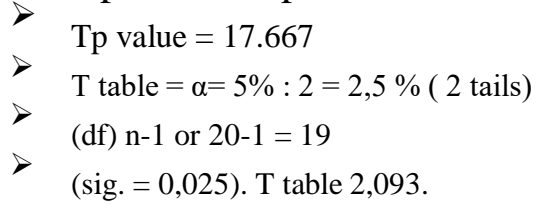

$\mathrm{T}$ value $>\mathrm{T}$ table $=17.667>2.093$ and $\mathrm{P}$ value $=0.000>0,05$.

\section{Students' Ability in Explaining Cases}

To know students' ability in explaining cases, the writer gave interview to the students. These are the score of the pretest;

Table2. A

Score Pretest of Experimental Group

\begin{tabular}{|l|c|c|l|l|l|l|c|}
\hline No & Name of students & P & G & V & F & Total score & Value \\
\hline 1. & $\mathrm{~A}$ & 2 & 3 & 3 & 2 & 10 & 50 \\
\hline
\end{tabular}


INTERACTION: Jurnal Pendidikan Bahasa: Vol. 5, No.1: Mei 2018

ISSN: 2406-9558; E-ISSN: 2406-9566

\begin{tabular}{|l|c|c|c|c|c|c|c|}
\hline 2. & B & 3 & 2 & 2 & 1 & 8 & 40 \\
\hline 3. & C & 3 & 2 & 2 & 3 & 10 & 50 \\
\hline 4. & D & 4 & 1 & 1 & 3 & 9 & 45 \\
\hline 5. & E & 2 & 2 & 1 & 2 & 7 & 35 \\
\hline 6. & F & 3 & 2 & 1 & 4 & 10 & 50 \\
\hline 7. & G & 3 & 2 & 3 & 2 & 10 & 50 \\
\hline 8. & H & 3 & 2 & 2 & 2 & 9 & 45 \\
\hline 9. & I & 4 & 2 & 2 & 2 & 10 & 50 \\
\hline 10. & J & 2 & 2 & 2 & 3 & 9 & 45 \\
\hline 11. & K & 3 & 3 & 2 & 2 & 10 & 50 \\
\hline 12. & L & 2 & 3 & 3 & 2 & 10 & 50 \\
\hline 13. & M & 3 & 2 & 2 & 3 & 10 & 50 \\
\hline 14. & N & 2 & 2 & 2 & 3 & 9 & 45 \\
\hline 15. & O & 2 & 1 & 1 & 3 & 7 & 35 \\
\hline 16. & P & 2 & 3 & 2 & 3 & 10 & 50 \\
\hline 17. & Q & 2 & 1 & 1 & 2 & 6 & 30 \\
\hline 18. & R & 2 & 2 & 3 & 2 & 9 & 45 \\
\hline 19. & S & 2 & 1 & 1 & 3 & 7 & 35 \\
\hline 20. & T & 3 & 2 & 2 & 3 & 10 & 50 \\
\hline & SUM & & & & & & 900 \\
\hline & MEAN & & & & & 45 \\
\hline
\end{tabular}

Table 2B.

Score Pretest of Control Group

\begin{tabular}{|l|l|l|l|l|l|l|l|}
\hline No & Name of students & P & G & V & F & Total score & Value \\
\hline
\end{tabular}


INTERACTION: Jurnal Pendidikan Bahasa: Vol. 5, No.1: Mei 2018

ISSN: 2406-9558; E-ISSN: 2406-9566

\begin{tabular}{|c|c|c|c|c|c|c|c|}
\hline 1. & $\mathrm{~A}$ & 3 & 3 & 2 & 2 & 10 & 50 \\
\hline 2. & B & 2 & 2 & 1 & 3 & 8 & 40 \\
\hline 3. & $\mathrm{C}$ & 3 & 3 & 2 & 2 & 10 & 50 \\
\hline 4. & $\mathrm{D}$ & 2 & 3 & 2 & 2 & 9 & 45 \\
\hline 5. & $\bar{E}$ & 3 & 2 & 2 & 3 & 10 & 50 \\
\hline 6. & $\bar{F}$ & 3 & 1 & 1 & 2 & 7 & 35 \\
\hline 7. & $\bar{G}$ & 3 & 2 & 1 & 4 & 10 & 50 \\
\hline 8. & $\mathrm{H}$ & 2 & 2 & 1 & 1 & 6 & 30 \\
\hline 9. & I & 2 & 2 & 2 & 2 & 8 & 40 \\
\hline 10. & $\mathrm{~J}$ & 3 & 2 & 2 & 3 & 10 & 50 \\
\hline 11. & $\mathrm{~K}$ & 2 & 3 & 2 & 3 & 10 & 50 \\
\hline 12. & $\mathrm{~L}$ & 1 & 2 & 1 & 2 & 6 & 30 \\
\hline 13. & $\bar{M}$ & 3 & 2 & 2 & 3 & 10 & 50 \\
\hline 14. & $\mathrm{~N}$ & 2 & 3 & 2 & 2 & 9 & 45 \\
\hline 15. & $\bar{O}$ & 3 & 2 & 2 & 3 & 10 & 50 \\
\hline 16. & $\mathrm{P}$ & 2 & 2 & 1 & 2 & 7 & 35 \\
\hline 17. & Q & 2 & 3 & 2 & 2 & 9 & 45 \\
\hline 18. & $\mathrm{R}$ & 3 & 2 & 3 & 2 & 10 & 50 \\
\hline 19. & $\bar{S}$ & 3 & 2 & 2 & 3 & 10 & 50 \\
\hline 20. & $\mathrm{~T}$ & 3 & 2 & 2 & 2 & 9 & 45 \\
\hline & SUM & & & & & & 890 \\
\hline & MEAN & & & & & & 44.5 \\
\hline
\end{tabular}

Note :

1 : Pronunciation

2 : Grammar 
3: Vocabulary

4 : Fluency

Based on the data analysis previously, the writer got the result of pretest from both Experimental group and Control group. Average of scores of experimental group was 45 , and average of scores Control group was 44, 5 . Based to the fact above the writer concluded that the students' ability in explaining cases were low. The classification of the student's quality was based on Sopia (2006: 23).

\begin{tabular}{|l|l|}
\hline Score & Criteria \\
\hline $90-100$ & Excellent \\
\hline $70-89$ & Good \\
\hline $60-69$ & Fair \\
\hline $50-59$ & Poor \\
\hline$<50$ & Failed \\
\hline
\end{tabular}

The frequency and the percentage of the result of pre-test in experimental group can be seen in table below:

Table 3.A the Pre-test Frequency and Percentage Result of Experimental Group

\begin{tabular}{|l|l|l|l|l|}
\hline No & Classification & \multirow{2}{*}{ Score } & Pretest \\
\cline { 4 - 5 } & & & Frequency (f) & Percentage \\
\hline 1 & Excellent & $90-100$ & - & - \\
\hline 2 & Good & $70-89$ & - & - \\
\hline 3 & Fair & $60-69$ & - & - \\
\hline 4 & Poor & $50-59$ & 10 & 50 \\
\hline 5 & Failed & $<50$ & 10 & 50 \\
\hline & Total & 20 & $100 \%$ \\
\hline
\end{tabular}

Table above show that 10 (50) out of 20 students were classified as poor, 10 (50) students out of 20 students were classified as failed and none of the students was classified as excellent and good.

The frequency and the percentage of the result of post-test in experimental group can be seen in table below: 
INTERACTION: Jurnal Pendidikan Bahasa: Vol. 5, No.1: Mei 2018

ISSN: 2406-9558; E-ISSN: 2406-9566

Table 3.B the Post-test Frequency and Percentage Result of Experimental Group

\begin{tabular}{|c|c|c|c|c|}
\hline \multirow[t]{2}{*}{ No } & \multirow[t]{2}{*}{ Classification } & \multirow[t]{2}{*}{ Score } & \multicolumn{2}{|l|}{ Pretest } \\
\hline & & & Frequency (f) & Percentage \\
\hline 1 & Excellent & $90-100$ & 2 & 10 \\
\hline 2 & Good & $70-89$ & 18 & 90 \\
\hline 3 & Fair & $60-69$ & - & - \\
\hline 4 & Poor & $50-59$ & - & - \\
\hline 5 & Failed & $<50$ & - & - \\
\hline & Total & & 20 & $100 \%$ \\
\hline
\end{tabular}

Table above show that 2 or $10 \%$ of 20 students were classified as excellent, 18 or $90 \%$ of 20 students were classified as good and none of the students was classified as fair, poor and failed.

Finally from the two variables above, the writer concluded that the students could not increase their ability in explaining cases well without Presentation Method.

Table 3.C Mean score of Pre-test and post-test of Experimental Group.

\begin{tabular}{|l|l|l|}
\hline No & Test & Mean score \\
\hline 1 & Pre-test & 45 \\
\hline 2 & Post-test & 79,25 \\
\hline
\end{tabular}

The frequency and the percentage of the result of pre-test in the control group can be seen in the table below:

Table 3.D The Pre-test Frequency and Percentage Result of Control Group.

\begin{tabular}{|c|c|c|c|c|}
\hline \multirow[t]{2}{*}{ No } & \multirow[t]{2}{*}{ Classification } & \multirow[t]{2}{*}{ Score } & \multicolumn{2}{|l|}{ Pretest } \\
\hline & & & Frequency (f) & Percentage \\
\hline 1 & Excellent & $90-100$ & S & - \\
\hline 2 & Good & 70-89 & - & - \\
\hline 3 & Fair & $60-69$ & - & - \\
\hline 4 & Poor & $50-59$ & 10 & 50 \\
\hline 5 & Failed & $<50$ & 10 & 50 \\
\hline & Total & & 20 & $100 \%$ \\
\hline
\end{tabular}


Table above show that 10 or $50 \%$ of 20 students were classified as poor, 10 or $50 \%$ students of 20 students were classified as failed and none of the students was classified as excellent and good.

The frequency and the percentage of the result of post-test class control group can be seen in the table below:

\section{Table 3.E The post-test Frequency and Percentage Result of} Control group.

\begin{tabular}{|l|l|l|l|l|}
\hline No & Classification & Score & Pretest \\
\cline { 4 - 5 } & & & Frequency (f) & Percentage \\
\hline 1 & Excellent & $90-100$ & - & - \\
\hline 2 & Good & $70-89$ & - & - \\
\hline 3 & Fair & $60-69$ & - & - \\
\hline 4 & Poor & $50-59$ & 2 & 10 \\
\hline 5 & Failed & $<50$ & 18 & 90 \\
\hline & Total & 20 & $100 \%$ \\
\hline
\end{tabular}

Table above show that, 2 or $10 \%$ of 20 students were classified as poor, and 16 or $80 \%$ students of 20 students were classified as failed and none of the students was classified as excellent and good.

Finally, from the two tables above, it concluded that the students could not increase their ability in explaining cases well without Presentation Method.

Table 3.F Mean score of Pre-test and post-test of Control Group.

\begin{tabular}{|l|l|l|}
\hline No & Test & Mean score \\
\hline 1 & Pre-test & 44.5 \\
\hline 2 & Post-test & 42.5 \\
\hline
\end{tabular}

\section{Hypothesis Testing}

After got the scores of $\mathrm{t}$ - value, the writer compare the result with the hypothesis is:

$>$ If the $\mathrm{T}$-value $<\mathrm{T}$ - table, means that $\mathrm{H} 0$ is rejected.

$>$ If the T-value > T-table, it means that $\mathrm{H} 1$ is accepted

In this case the writer got the score of t- value was 17,667. Then the result of t-value is compared with t-table with sig $=5 \%(0,05)$, and df is 19. It is got from: Total of sample $-1=20-1$

$$
=19
$$

After the value of df is known, then look for value of t-table with 
INTERACTION: Jurnal Pendidikan Bahasa: Vol. 5, No.1: Mei 2018

ISSN: 2406-9558; E-ISSN: 2406-9566

$\alpha=0,05(5 \%)$ and $\mathrm{df}$ is 19 was 2.093 .

Based on the result above, it means that Presentation Method is effective, because it is agreed with the hypothesis is: $\mathrm{H} 1$ is accepted if $\mathrm{t}$-value > $\mathrm{t}$-table $(17,667>2,093)$ and Presentation Method can increase students' ability in explaining cases.

\section{Discussion}

Based on the data description and basic testing analysis previously the writer can explain the research finding as follow;

Presentation Method is effective to increase student's ability in explaining cases, because students always practice to explain cases, it will increase their ability in explaining cases.

Pretest the students speaking ability very low. After collecting the data from the frequency and applying through percentage, it's showed that the students of Madrasah Aliyah Negeri Sorong have good score English subject and they are able to explain cases.

Finally, the writer summarized that in line with the first problem statement that is Presentation Method could increase student's ability in explaining cases, it could be said that based on the data analysis, the Presentation Method could improve the students' ability in explaining cases.

\section{CONCLUSION}

This research showed that there was increasing scores of students at experimental group. The mean pretest of both experimental group and control group before were 45. Then after treatment was given to experimental group the mean was 80 . But the mean of control group was 40,25 . It means that Presentation Method is effective to increase students' ability in explaining cases.

Then the result of hypothesis testing previously showed that $\mathrm{H} 1$ is accepted because $\mathrm{t}$ value $>$ t-table $=17,667>2,093$

\section{REFERENCE}

Ahmadi Gilani, M. R., Nizam Ismail, H., \& Pourhossein Gilakjani, A. (2012). Impact of learning reading strategy on students' reading comprehension proficiency. The International Journal of Language Learning and Applied Linguistics World ( IJLLALW ), 1 (1), 78-95.

Anggraeni M.S Lagalo (2012). The Application of Presentation Method to Increase Students Ability at The Tenth Grade Students of Man Batudaa.

Corbeil, G. (2007). Can PowerPoint presentations effectively replace text-books and blackboards for teaching grammar? Do Students Find Them an Effective Learning Tool ? CALICO Journal, 24 (3), 631-656. 
Ilter, B. G., (2009). Effect of technology on motivation in EFL classrooms. Turkish Online Journal of Distance Education, 10, No. 4, Art. 9.

Munali, (2013). Improving Student's Speaking Ability Through Presentation at The Second Grade of MA Muhammadiyah Aimas.

Oommen, A. (2012). Teaching English as a global language in smart classrooms with power-point presentation. English Language Teaching, 5, No. 12, 54.

Ozaslan, E. N., \& Maden, Z. (2013). The use of power point presentations at in the department of foreign language education at middle east technical university. Middle Eastern \& African Journal of Educational Research, Issue 2.

Segundo, E. \& Salazar, D. (2011). The efficacy of using power point presentations to improve grammar and vocabulary learning among students of the intermediate II level (Regular program) of El Cultural Centro Peruano Americano in Trujillo, Peru. Repositorio institucional PIRHUAUniversided de Piura.

Stepp-Greany, J. (2002). Student perceptions on language learning in a technological environment: Implications for the new millennium. Language Learning \& Technology, 6(1), 165-180.

Wang, M. J. (2011). Using multimodal presentation software and peer group Discussion in learning English as a second language. Australasian Journal of Educational Technology, 27(6), 907-923.

Wartinbee, E. (2009). The value of technology in the EFL and ESL classrooms: using the smartpen to enhance the productivity and effectiveness of ESL instruction. Technology in the EFL and ESL Classroom, Peabody College, Vanderbilt University.

Ybarra, R., \& Green, T. (2003). Using technology to help ESL / EFL students develop language skills. The Internet TESL Journal, IX, 3. 